University of Nebraska - Lincoln

DigitalCommons@University of Nebraska - Lincoln

2020

Defense Against the Dark Arts: Justice Jackson, Justice Kennedy and the No-Compelled-Speech Doctrine

Richard F. Duncan

Follow this and additional works at: https://digitalcommons.unl.edu/lawfacpub

Part of the First Amendment Commons

This Article is brought to you for free and open access by the Law, College of at DigitalCommons@University of Nebraska - Lincoln. It has been accepted for inclusion in College of Law, Faculty Publications by an authorized administrator of DigitalCommons@University of Nebraska - Lincoln. 


\title{
DEFENSE AGAINST THE DARK ARTS: JUSTICE JACKSON, JUSTICE KENNEDY AND THE NO-COMPELLED-SPEECHDOCTRINE
}

\author{
Richard F. Duncan*
}

"The one thing that doesn't abide by majority rule is a person's conscience." -Atticus Finch ${ }^{1}$

"Your statute cannot condemn me to death for such silence, for neither your statute nor any laws in the world punish people except for words or deeds, surely not for keeping silence." -Sir Thomas More $^{2}$

"The possibility of enforcing not only complete obedience to the will of the State, but complete uniformity of opinion on all subjects, now existed for the first time." -George Orwell ${ }^{3}$

\section{INTRODUCTION}

According to Justice Anthony M. Kennedy, "The right to think is the beginning of freedom, and speech must be protected from the government because speech is the beginning of thought." ${ }^{4}$ If this is so, and I believe it is, then the greatest threat to freedom, the darkest of the dark arts of government, occurs when the law compels persons to speak and thus commandeers their intellectual autonomy. ${ }^{5}$ Only a vibrant First Amendment is an adequate defense against this darkest of the dark arts. ${ }^{6}$

\footnotetext{
Sherman S. Welpton, Jr. Professor of Law and Warren R. Wise Professor of Law, University of Nebraska College of Law.

1 Harper Lee, TO Kill a MoCkingBiRd 120 (HarperCollins, 1st Perennial Classics ed. 2002) (1960).

2 Christopher Holdis, St. Thomas More 228 (Burns \& Oates, rev. ed. 1961) (1934).

3 GeORGE ORwELL, 1984206 (Penguin Group 1977) (1949). "Nothing was your own except the few cubic centimeters inside your skull." Id. at 27.

4 Ashcroft v. Free Speech Coal., 535 U.S. 234, 253 (2002).

$5 \quad$ As expressed by Justice Kennedy, "governments are most dangerous when they try to tell people what to think." HeLen J. KNOWLES, The TiE GOES TO FREEDOM 87 (updated ed. 2019).

6 In the magical world of Harry Potter, "Defense Against the Dark Arts" is the class taught at Hogwarts to teach students how to defend themselves against the dark forces. J.K. ROWLING, HARRY POTTER AND THE SORCERER's STONE 66-67 (First Am. ed., Arthur A. Levine Books 1998) (1997). Harry's first Defense Against the Dark Arts teacher was Professor Quirrell and his first Dark Arts textbook was Dark Forces: A Guide to Self-Protection by Quentin Trimble. Id. at 67, 70 .
} 
This Article traces the Supreme Court's First Amendment jurisprudence protecting speaker autonomy and the "right not to speak" from its origins in the flag salute cases to the present. In particular, I focus on two magnificent judicial opinions defending this fundamental free speech right, the majority opinion of Justice Jackson in West Virginia State Board of Education v. Barnette 7 and the concurring opinion of Justice Kennedy in National Institute of Family \& Life Advocates $v$. Becerra (NIFLA). 8 These two eloquent and powerful opinions are true landmarks of liberty and strong shields against an authoritarian government's tyrannical attempts to coerce ideological orthodoxy by compelling individuals to say things they wish not to say. In Justice Kennedy's case, his concurring opinion in NIFLA was issued near the end of his final term on the Supreme Court, and thus it represents an exclamation point on his wonderful legacy of protecting freedom of thought and freedom of speech. ${ }^{9}$ Although these opinions are separated by seventy-five years, they share a common understanding of the importance of the First Amendment for the protection of intellectual autonomy from authoritarian officials and compelled ideological conformity.

I. The Flag Salute Cases:

\section{JUSTICE JACKSON's ELOQUENT RESPONSE TO JUSTICE FRANKFURTER}

\section{A. Justice Frankfurter and the First Flag Salute Case}

In 1898, New York became the first state to enact a mandatory flag salute law. ${ }^{10}$ However, the flag salute movement soon took off like a rocket's red glare, led by a diverse assortment of groups, including the Daughters of the American Revolution, the Ku Klux Klan, and the

$8 \quad 138$ S. Ct. 2361, 2378 (2018) (Kennedy, J., concurring).

9 David French, In Defense of Free Speech, Justice Thomas Wielded the Scalpel, but Justice Kennedy Brought the Hammer, NAT'L ReV. (June 26, 2018), https://www. nationalreview.com/corner/in-defense-of-free-speech-justice-thomas-wielded-the-scalpel-but -justice-kennedy-brought-the-hammer/ ("Justice Kennedy's concurrence ... was a short but astonishing opinion, one that-along with his opinion in Masterpiece Cakeshop-suggests that his judicial legacy will now include two of the more powerful court statements for people of faith in recent Supreme Court jurisprudence.").

10 Winston Bowman, The Flag Salute Cases, 2017 FED. Jud. CTR. 2. 
American Legion. ${ }^{11}$ By 1943, when Barnette was decided, all forty-eight states had adopted some version of compulsory flag salute. ${ }^{12}$

Onto this field strode the Jehovah's Witnesses, a religious denomination that took very seriously the Biblical command in Exodus 20:3-5 about not bowing down before any "graven image." ${ }^{13}$ Indeed, as Winston Bowman noted, in Nazi Germany "Jehovah's Witnesses had refused to engage in the Nazi salute on the grounds that it reflected a form of worship for a secular power." 14 As a result, "they suffered atrocious persecution" under the Nazi regime and thousands died in concentration camps for the crime of following their religious consciences. ${ }^{15}$

In America, although Jehovah's Witnesses were not executed or placed in concentration camps, they did experience a level of persecution when they enrolled their children in public schools. ${ }^{16}$ The two landmark Supreme Court cases, Minersville School District v. Gobitis ${ }^{17}$ and Barnette, ${ }^{18}$ each involved schoolchildren ${ }^{19}$-William and Lillian Gobitas in

11 Id. The Daughters of the American Revolution and the Ku Klux Klan supported the movement in order to "encourage patriotism as a bulwark against communism." Id. The American Legion, on the other hand, made mandatory flag salutes its "signal issue," all in the cause of advancing its goal of "one hundred percent Americanism." Id.

12 Bowman, supra note 10, at 2. Even in jurisdictions without a flag salute law, many "schools and teachers often required students to participate in such a ritual as a matter of course." Id.

${ }_{13} I d$. at 4. See Exodus 20:3-5 (King James Version), for a provision of the full text of the pertinent Biblical command:

Thou shalt have no other gods before me. Thou shalt not make unto thee any graven image, or any likeness of any thing that is in heaven above, or that is in the earth beneath, or that is in the water under the earth. Thou shalt not bow down thyself to them, nor serve them: for I the Lord thy God am a jealous God, visiting the iniquity of the fathers upon the children unto the third and fourth generation of them that hate me...

14 Bowman, supra note 10 , at $2-3$.

15 Id. at 3.

16 See W. Va. State Bd. of Educ. v. Barnette, 319 U.S. 624, 630 (1943) ("Children of this faith have been expelled from school and are threatened with exclusion for no other cause. Officials threaten to send them to reformatories maintained for criminally inclined juveniles."). In fact, "[a]ttempts have been made in many states to repress or regulate [Jehovah's Witnesses] by legislation," but Jehovah's Witnesses have "uniformly resisted" such oppression. Edward F. Waite, The Debt of Constitutional Law to Jehovah's Witnesses, 28 MinN. L. REV. 209, 223 (1944). Robert Ferguson marked this resistance when he observed that, in the period between 1938 and 1944 alone. Jehovah's Witnesses were parties in thirty-one cases. Robert A. Ferguson, The Judicial Opinion as Literary Genre, 2 YALE J.L., \& HUMAN. 201, 203 (1990). Those cases resulted in "sixteen civil liberties opinions from the Supreme Court." Id.

$17 \quad 310$ U.S. $586(1940)$

$18 \quad 319$ U.S. at 624.

19 In both Gobitis and Barnette, the case captions misspelled the family names of the parties. Bowman, supra note 10 , at 19 . In the former, the family name is Gobitas with an "a" not an " $i$," and in the latter, it is Barnett without an " $\mathrm{e}$ " at the end. $I d$. 
Gobitis, and Gathie and Marie Barnett in Barnette-who were Jehovah's Witnesses disciplined for refusing to salute the flag. ${ }^{20}$

In Gobitis, the children "were expelled from the public schools of Minersville, Pennsylvania, for refusing to salute the national flag as part of a daily school exercise." ${ }^{21}$ As a result of their expulsion, the Gobitas children were deprived of a free public education and their parents were required to bear the financial burden of paying for a private school education. ${ }^{22}$ Because the Gobitas family believed, in accordance with their Jehovah's Witness faith, that they were forbidden by Biblical commands from bowing down before graven images, such as the flag, ${ }^{23}$ the family "sought to enjoin the authorities from continuing to exact participation in the flag-salute ceremony as a condition of ... attendance at the Minersville school." 24 Since Gobitis was decided in the early days of incorporation of the Bill of Rights through the Due Process Clause of the Fourteenth Amendment, the Court described their claim as asking it to determine whether their free exercise of religion was protected in this case by "the Fourteenth [Amendment] through its absorption of the First." 25 Thus, the question presented in Gobitis was not whether a compelled affirmation of belief violated the Free Speech Clause and the rights of all dissenters to refuse to participate, but rather whether the Gobitas children were entitled to a religious liberty exemption from the pledge requirement under the Free Exercise Clause (as "absorbed" by the Fourteenth Amendment). ${ }^{26}$

Justice Frankfurter, writing for the majority in an eight to one decision, viewed the case as one in which a person's "religious duty [comes] into conflict with the secular interests of his fellow-men." 27 Thus, the issue before the Court was this: "When does the constitutional guarantee compel exemption from doing what society thinks necessary for the promotion of some great common end, or from a penalty for conduct which appears dangerous to the general good?" 28

20 See id. at 4-5, 19 (discussing the Gobitas and Barnett children's punishment-expulsion and daily suspension, respectively-for refusing to salute the flag).

21310 U.S. at 591. The flag salute ceremony required the placing of the right hand on the breast and reciting the pledge in unison: "I pledge allegiance to my flag, and to the Republic for which it stands; one nation indivisible, with liberty and justice for all." Id. Finally, "[w]hile the words are spoken, teachers and pupils extend their right hands in salute to the flag." Id.

$22 I d$. at 592 .

23 Id. see also id. at 592 n.1 (explaining that Jehovah Witnesses rely on Exodus $20: 3-5$ to explain why they refuse to salute the flag).

24 Id. at 592.

$25 I d$ at 593 .

$26 \quad I d$.

27 Id.

28 Id. 
Because the case before the Gobitis Court involved the curriculum of a public school, the power of the government to "train[] children in patriotic impulses by these compulsions" was at its zenith. ${ }^{29}$ As Justice Frankfurter put it so clearly, "the courtroom is not the arena for debating issues of educational policy," the Supreme Court is not "the school board for the country" and, as such, "[t]hat authority has not been given to this Court, nor should we assume it." 30

The Court held that the mandatory pledge requirement did not violate the free exercise rights of religious dissenters. ${ }^{31}$ Although the "[g]overnment may not interfere with organized or individual expression of belief or disbelief," the Constitution does not "compel exemption from doing what society thinks necessary for the promotion of some great common end." 32 In other words, although the right to believe that bowing down before graven images violates the commands of God is protected by the Constitution, the right to act upon that belief is not protected from "a general law not aimed at the promotion or restriction of religious beliefs." 33 Therefore, it was perfectly constitutional for the school authorities to expel children who refused to salute the flag based upon their sincerely held religious beliefs. ${ }^{34}$ Their remedy was not constitutional protection in the courts, but rather the political right to seek changes in the law "before legislative assemblies." 35

Perhaps what is most remarkable about the Gobitis decision is how the Court seemed to believe the case was easy to decide. In the eyes of Justice Frankfurter and the majority, requiring schoolchildren to recite the Pledge was a matter of national unity and national cohesion, and "[n]ational unity is the basis of national security." 36 Indeed, echoing President Lincoln, the Court said the case created an existential dilemma

29 Id. at 598.

30 Id. For a recent analysis of freedom of expression in public schools, see generally Justin Driver, The Schoolhouse Gate 72-140 (2018). Although students have a constitutional right to freedom of expression on public school campuses, school authorities have substantial power to govern student speech "that is lewd, school-sponsored, or pro-drug." Id. at 125; see also Richard W. Garnett, Can There Really Be "Free Speech" In Public Schools?, 12 LEWIS \& CLARK L. REV. 45, 47-48, 55 (2008) (discussing the power of public schools "to regulate speech in the service of their educational mission"). A school requirement regarding the recital of the Pledge of Allegiance is, of course, a school-sponsored activity designed to teach students the meaning of the flag. See Mark Strasser, Establishing the Pledge: On Coercion, Endorsement, and the Marsh Wild Card, 40 IND. L. REv. 529, 533 (2007) ("Rather than support religion, the salute and pledge 'are directed to a justifiable end in the conduct of education in the public schools." (quoting Nicholls v. Lynn, 7 N.E.2d 577, 580 (Mass. 1937)).

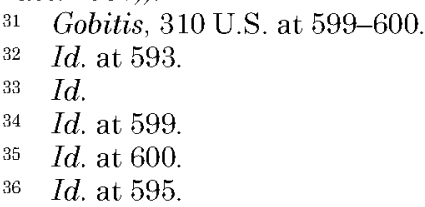


for our Nation- "Must a government of necessity be too strong for the liberties of its people, or too weak to maintain its own existence." ${ }^{77}$ Justice Frankfurter essentially concluded that with the survival of the Republic at stake, the problems of a few schoolchildren who were Jehovah's Witnesses "don't amount to a hill of beans in this crazy world." 38

Justice Stone issued a powerful dissenting opinion in Gobitis, one based upon the constitutional primacy "of freedom of the human mind and spirit." 39 As he put it so eloquently, "The very essence of . . liberty" protected by the Constitution "is the freedom of the individual from compulsion as to what he shall think and what he shall say, at least where the compulsion is to bear false witness to his religion." 40 Therefore, these constitutional guaranties, "withhold from the state any authority to compel belief or the expression of it where that expression violates religious convictions, whatever may be the legislative view of the desirability of such compulsion." 41 The state must resort to "other ways to teach loyalty and patriotism" and the importance of the flag as a source of national unity. ${ }^{42}$ Moreover, in contrast to the majority's extreme deference to state legislatures and local school boards, Justice Stone emphasized "the importance of a searching judicial inquiry" rather than surrendering "the constitutional protection of the liberty of small minorities to the popular will." 43 Although Stone stood alone against Frankfurter's majority of eight, his powerful and persuasive dissent was soon to be vindicated.

Gobitis was decided on June 3, 1940, ${ }^{44}$ at a time when "French and British troops were desperately being evacuated from Dunkirk." 45 Indeed, Gobitis was decided at a time when Hitler's "German forces were occupying Norway and Denmark, and were about to invade the Low Countries and France." 46 The reaction to the decision by toxically

$37 \quad I d$. at 596 (quoting President Lincoln).

38 Id. at 599-600; CASABLANCA (Warner Bros. Pictures Inc. 1942). To explain why the war effort is more important than personal preferences, Humphrey Bogart's character, Rick Blaine, said: "Ilsa, I'm no good at being noble, but it doesn't take much to see that the problems of three little people don't amount to a hill of beans in this crazy world. Someday you'll understand that." CASABLANCA (Warner Bros. Pictures Inc. 1942).

39310 U.S. at 604 (Stone, J., dissenting)

40 Id.

41 Id.

$42 \quad I d$. at $603-04$

$43 \quad$ Id. at 606 .

$44 \quad I d$. at 586

45 Vincent Blasi \& Seana V. Shiffrin, The Story of West Virginia State Board of Education v. Barnette: The Pledge of Allegiance and the Freedom of Thought, in FIRST AMEndMEnT Stories 99, 109 (Richard W. Garnett \& Andrew Koppelman eds., 2012).

46 William M. WieceK, 12 The Birth of the Modern Constitution: The United States Supreme CourT, 1941-1953, at 221 (Stanley N. Katz, ed. 2006). This led some courthouse jokers to refer to Justice Frankfurter's majority opinion in Gobitis as "Felix's Fall-of-France opinion." Id. at 222. 
"patriotic" Americans was shameful. Jehovah's Witnesses were attacked, their property was vandalized, and some were even "tarred and feathered." ${ }^{7}$ Shamefully, "in August 1940, Albert Walkenhorst was lured from his home in Norfolk, Nebraska, by a group of vigilantes posing as fellow Witnesses and castrated." 48

\section{B. Justice Jackson and the Second Flag Salute Case}

Less than three years after Gobitis poisoned the First Amendment, it was explicitly overruled by Barnette.49 "Barnette," says Professor (now Judge) Jay Bybee, "was an antidote, the 'anti-Gobitis'-what Brown $v$. Board of Education was to Plessy, or the Fourteenth Amendment was to Dred Scott."50 Barnette's overruling of Gobitis is also remarkable because of its "daring switch of rationale" and the eloquent yet vague prose of Justice Jackson in his landmark majority opinion. ${ }^{51}$ Indeed, as Vincent Blasi and Seana Shiffrin observe, "Seldom has a case outcome seemed so obviously correct as that in Barnette and yet so difficult to justify." 52 Barnette is certainly canonical, a towering landmark of First Amendment jurisprudence. ${ }^{53}$

A great deal had happened in the short time between Gobitis and Barnette. The United States had entered the war against Japan and Nazi Germany. ${ }^{4}$ Two members of the Gobitis Court, Chief Justice Hughes and Justice McReynolds, had retired, and two new Roosevelt nominees, Justice Jackson and Justice Rutledge, had been confirmed. ${ }^{55}$ Remarkably, "three members of the Gobitis majority, Justices Black, Douglas, and Murphy," publicly announced that they "had changed their minds about

47 Blasi \& Shiffrin, supra note 45 , at $109-10$.
48 Id. at 110.
49 W. Va. State Bd. of Educ. v. Barnette, 319 U.S. 624,642 (1943).
50 Jay S. Bybee, Common Ground: Robert Jackson, Antonin Scalia, and a Power Theory of the First Amendment, 75 TUL. L. REV. 251, 254 (2000).

Seldom in its history has a constitutional controversy generated such antipathy within the Court, such widespread civic violence directly attributable to a judicial decision, such anticipatory public recanting by individual justices, such a daring switch of rationale, [and] such memorable and pointed prose in a majority opinion ....

Blasi \& Shiffrin, supra note 45 , at 99-100

51 Blasi \& Shiffrin, supra note 45 , at 99-100.

52 Id. at 100 .

53 See Paul Horwitz, A Close Reading of Barnette, In Honor of Vincent Blasi, 13 FIU L. REV. 689, 694-95 (2019) ("Barnette is one of the key opinions in the canon of First Amendment Law. . . . Between them, the four opinions in Barnette read like a syllabus of the major issues in First Amendment Law between 1943 and 2018.")

54 Blasi \& Shiffrin, supra note 45 , at 112.

55 Id. at $112-13$. 
the constitutional questions presented by compulsory flag ceremonies in public schools." 56

Shortly after the Court's decision in Gobitis, the West Virginia legislature amended its laws to require all schools to teach history and civics in a manner designed to foster "the ideals, principles and spirit of Americanism." 57 In order to carry out the purpose of this law, the West Virginia Board of Education adopted a resolution on January 9, 1942, requiring all teachers and pupils to salute the flag. ${ }^{88}$ The Board also decreed that refusal to salute the flag shall "be regarded as an act of insubordination, and shall be dealt with accordingly." 59 The penalty for refusing to salute the flag was expulsion from school, which carried with it the risk of truancy and criminal sanctions for both the "delinquent" child and his parents. ${ }^{60}$

In Barnette, after children from three Jehovah's Witness' families were expelled for refusing to salute the flag, attorneys for the Barnetts and other families brought a class action in federal court seeking to enjoin enforcement of the flag salute policy. ${ }^{61}$ After the plaintiffs prevailed before a three-judge panel in the district court, the state appealed directly to the United States Supreme Court. ${ }^{2}$ Justice Jackson, writing for a 6-3 majority, affirmed the district court's injunction against enforcement of the flag salute law and explicitly overruled Gobitis. ${ }^{63}$ Justice Jackson's opinion in the case is iconic and still reverberates in the jurisprudence of the First Amendment. Indeed, in the words of Professor Paul Horwitz, Jackson's opinion in Barnette "is great because it is rich, fascinating, eloquent, sweeping, and powerful."64

56 Id. at 113; Jones v. Opelika, 316 U.S. 584, 623-24 (1942) (Black, Douglas, and Murphy, JJ., dissenting) ("Since we joined in the opinion in the Gobitis case, we think this is an appropriate occasion to state that we now believe that it also was wrongly decided.").

57 W. Va. State Bd. of Educ. v. Barnette, 319 U.S. 624, 625 (1943).

$58 \quad I d$. at 626

$59 \quad I d$.

60 Id. at 629 . If convicted, the parents were "subject to [a] fine not exceeding $\$ 50$ and jail term not exceeding thirty days." $I d$. Children who were expelled for refusing to salute the flag were also subject to being sent "to reformatories maintained for criminally inclined juveniles." Id at 630 .

$61 \quad$ Id. at 629 ; Blasi \& Shiffrin, supra note 45 , at 113 . In order to avoid prosecution for truancy, Gathie and Marie Barnett, the daughters of the lead plaintiff in Barnette, would "travel to school each morning" only to be "sent home for refusing to salute the flag." Bowman, supra note 10 , at 19 .

62 Barnette v. W. Va. State Bd. of Educ., 47 F. Supp. 251, 255 (S.D. W. Va. 1942) (granting Barnett's injunction against the school board); Barnette, 319 U.S. at 630 (reviewing the state Board of Education's direct appeal of the lower district court's decision).

63 Barnette, 319 U.S. at 642.

64 Horwitz, supra note 53 , at 695 . Horwitz goes on to say that the opinion "is not great because [its] passages are clear or clearly right, but because they feel clearly right." Id. at 696. 
Although the Barnette majority explicitly overruled Gobitis, Justice Jackson made clear that the decision was not based upon religious liberty, 65 but rather upon "intellectual individualism" 66 and the free speech right of the individual to resist "[c]ompulsory unification of opinion." 67 For the first time, the Supreme Court recognized that freedom of speech protects both the right to speak and the right to refrain from speaking: "To sustain the compulsory flag salute we are required to say that a Bill of Rights which guards the individual's right to speak his own mind, left it open to public authorities to compel him to utter what is not in his mind."68

The Court's move from religious freedom to free speech was very significant because rather than focus on whether a few religious dissenters were entitled to a free exercise exemption from the flag salute requirement, the issue before the Court became whether the states even have "power ... to impose the flag salute discipline upon school children in general." 69 If the state lacked power to compel the flag salute, the requirement would be categorically unconstitutional without any balancing or weighing of competing interests. Remarkably, "[t]his re-conception of the central constitutional issues at stake came largely at the Court's own initiative," because the briefs in support of the children and their families "had focused almost exclusively on freedom of religion."70

Justice Jackson framed the question presented in the case brilliantly so as to imply a clear answer to the issue: "The question which underlies the flag salute controversy is whether such a ceremony so touching matters of opinion and political attitude may be imposed upon the individual by official authority under powers committed to any political organization under our Constitution. We examine rather than assume existence of this power ..."71 Rather than viewing the case as posing an existential threat to the survival of the Republic, as Justice Frankfurter maintained in Gobitis, ${ }^{72}$ Justice Jackson observed "that the strength of government to maintain itself' was not threatened by a First Amendment protecting a "handful of children" from being expelled for refusing to

65 Barnette, 319 U.S. at 634 ("Nor does the issue as we see it turn on one's possession of particular religious views or the sincerity with which they are held."); see also id. at 635 (noting that Gobitis "only examined and rejected a claim based on religious beliefs of immunity from an unquestioned general rule").

66 Id. at $641-42$.

67 Id. at 641 .

68 Id. at 634 .

69 Id. at 635.

70 Blasi \& Shiffrin, supra note 45 , at 115

71 Barnette, 319 U.S. at $635-36$.

72 See supra notes $36-38$ and accompanying text. 
participate in the flag salute. ${ }^{73}$ Indeed, ordered liberty under a Bill of Rights "tends to diminish fear and jealousy of strong government, and by making us feel safe to live under it makes for its better support." 74

Thus, the issue for Justice Jackson and the majority was not a choice between weak and strong government, but rather between "individual freedom of mind" and a government-mandated "uniformity for which history indicates a disappointing and disastrous end." 75 Indeed, the Court acknowledged explicitly that an important purpose of freedom of speech under the First Amendment is to nip authoritarian government in the bud by denying tyrants—including "village tyrants"76 - the power to "coerce uniformity of sentiment" by compelling flag salutes or other affirmations of belief. ${ }^{77}$ Responding to "the very heart of the Gobitis opinion" and its recognition of the grave importance of national unity, ${ }^{78}$ Jackson composed an eloquent indictment of authoritarian government that still stirs the souls of lovers of liberty today:

As governmental pressure toward unity becomes greater, so strife becomes more bitter as to whose unity it shall be. Probably no deeper division of our people could proceed from any provocation than from finding it necessary to choose what doctrine and whose program public educational officials shall compel youth to unite in embracing. Ultimate futility of such attempts to compel coherence is the lesson of every such effort from the Roman drive to stamp out Christianity as a disturber of its pagan unity, the Inquisition, as a means to religious and dynastic unity, the Siberian exiles as a means to Russian unity, down to the fast failing efforts of our present totalitarian enemies. Those who begin coercive elimination of dissent soon find themselves exterminating dissenters. Compulsory unification of opinion achieves only the unanimity of the graveyard. ${ }^{79}$

73 Barnette, 319 U.S. at 636

74 Id.

$75 \quad I d$ at 637 .

76 Id. at 638; see also id. at 641 ("We set up government by consent of the governed, and the Bill of Rights denies those in power any legal opportunity to coerce that consent."). No such tyrant "who acts under the color of law is beyond reach of the Constitution." Id. at 638.

77 Id. at 640 .

78 Id. Justice Jackson affirmed the importance of national unity but observed that the problem with a mandatory flag salute policy "is whether under our Constitution compulsion as here employed is a permissible means for its achievement." Id.

79 Id. at 641. 
To illustrate how authoritarian government compels speech from its citizens, Justice Jackson specifically listed three historical examples of such tyranny: first, he noted the persecution of early Christians for refusing "to participate in ceremonies before the statue of the emperor;" 80 second, he recounted "[t]he story of William Tell's sentence to shoot an apple off his son's head for refusal to salute a bailiff's hat;" 81 and finally, he spoke of William Penn and the Quakers who "suffered punishment rather than uncover their heads in deference to any civil authority." 82 Even a symbol as widely revered as our Nation's flag can mean different things to different people. ${ }^{83}$ Thus, for the government to compel schoolchildren to salute the flag is tyrannical and even worse than compelled silence because it invades the private space of one's mind and beliefs. ${ }^{84}$ As Professor Robert George said: "Ordinary authoritarians are content to forbid people from saying things they know or believe to be true. Totalitarians insist on forcing people to say things they know or believe to be untrue." 85

And protection against these tyrannical features of authoritarianism and totalitarianism - the constitutional shelter for those who seek to dissent from government-imposed flag salutes and affirmations of belief-was created by Justice Jackson's immortal "fixed star" passage in Barnette:

If there is any fixed star in our constitutional constellation, it is that no official, high or petty, can prescribe what shall be orthodox in politics, nationalism, religion, or other matters of opinion, or force citizens to confess by word or act their faith therein. If there are any circumstances which permit an exception, they do not now occur to us.

We think the action of the local authorities in compelling the flag salute and pledge transcends constitutional limitations on their power and invades the sphere of intellect and spirit

\section{$80 \quad$ Id. at 633 n. 13 .}

81 Id.

82 Id.

83 Id. at 632-33 ("A person gets from a symbol the meaning he puts into it, and what is one man's comfort and inspiration is another's jest and scorn."). For example, in July of 2019, Nike cancelled the release of a sneaker featuring a Betsy Ross 13-star flag design after Colin Kaepernick, a former NFL quarterback and political activist, "privately criticized the design to Nike." Tiffany Hsu et al., Nike Drops 'Betsy Ross Flag' Sneaker After Kaepernick Criticizes It, N.Y. TIMES (July 2, 2019), https://www.nytimes.com/2019/07/02/business/betsyross-shoe-kaepernick-nike.html?searchResultPosition $=1$.

84 Barnette, 319 U.S. at 633-34 ("It would seem that involuntary affirmation could be commanded only on even more immediate and urgent grounds than silence.").

85 Robert P. George (@RobertPGeorge), FACEBOOK (Aug. 2, 2017), https:/www.facebook.com/RobertPGeorge/posts/10155417655377906. 
which it is the purpose of the First Amendment to our Constitution to reserve from all official control. ${ }^{86}$

Government-compelled affirmations of belief and speech must be nipped in the bud lest they lead to ever more authoritarian or totalitarian inquisitions. ${ }^{87}$ As Justice Jackson put it, "the First Amendment to our Constitution was designed to avoid these ends by avoiding these beginnings." 88 Thus, in Barnette the Free Speech Clause became a strong defense for individual liberty against the dark arts of totalitarian and authoritarian laws compelling speech. 89

Justice Black and Justice Douglas, who were part of the Gobitis majority upholding the Minersville flag salute policy, ${ }^{90}$ wrote a brief but important concurring opinion to explain the "reasons for [their] change of view."91 "Love of country," they declared, "must spring from willing hearts and free minds" and a law that compels affirmations of belief "when enforced against conscientious objectors ... is a handy implement for disguised religious persecution." 92 Although the Barnette Court's holding protects a general right under the Free Speech Clause to speaker autonomy, the concurrence demonstrates how free speech for everyone necessarily entails freedom for each one. ${ }^{93}$ The Free Speech Clause protects secular conscientious objectors and religious conscientious objectors; it protects one component of religious liberty by protecting free speech for all. ${ }^{94}$

Justice Frankfurter issued a dissent which has been described as a "combined jeremiad and lamentation from a constitutional prophet wounded by the jurisprudential heresies of his colleagues on the bench." 95

$86 \quad 319$ U.S. at 642.

87 See Richard Primus, A Brooding Omnipresence: Totalitarianism in Postwar Constitutional Thought, 106 YALE L.J. 423, 437-39 (1996) (discussing how the Barnette decision was largely influenced by anti-Nazism and anti-Sovietism movements).

88 Barnette, 319 U.S. at 641.

89 Id. at $641-42$

90 See supra note 56 and accompanying text.

91 Barnette, 319 U.S. at 643 (Black \& Douglas, JJ., concurring).

92 Id. at 644 .

93 Compare id. at 642 (majority opinion) (explaining how the First Amendment is designed to prevent the government from invading "the sphere of intellect and spirit"), with id. at 643-44 (Black \& Douglas, JJ., concurring) ("These laws must, to be consistent with the First Amendment, permit the widest toleration of conflicting viewpoints consistent with a society of free men.").

$94 I d$. at 634-35, 638-39 (majority opinion) ("While religion supplies appellees' motive for enduring the discomforts of making the issue in this case, many citizens who do not share these religious views hold such a compulsory rite to infringe constitutional liberty of the individual."); $i d$. at 644 (Black and Douglas, JJ., concurring) (describing how the enforcement of a ceremony against conscientious objectors "is a handy implement for disguised religious persecution" and "is inconsistent with our Constitution's plan and purpose").

95 Blasi \& Shiffrin, supra note 45 , at 119. 
Another way of understanding the duel between Justice Frankfurter and Justice Jackson is to view it as a collision between excessive judicial restraint and well-focused judicial engagement. Justice Frankfurter asserted that the "only and very narrow function" of judicial review under the First Amendment is "to determine whether within the broad grant of authority vested in legislatures they have exercised a judgment for which reasonable justification can be offered." 96 Protection of free speech is not a question of constitutional law for the courts to protect, but one of politics to be decided by "the ballot" and "the processes of democratic government." 97 For Justice Jackson, however, courts must engage and protect explicit constitutional liberties: "The very purpose of a Bill of Rights was to withdraw certain subjects from the vicissitudes of political controversy, to place them beyond the reach of majorities and officials and to establish them as legal principles to be applied by the courts." 98 Liberties explicitly protected by the Constitution, such as "free speech" and "freedom of worship," are "fundamental rights [that] may not be submitted to a vote" and that "depend on the outcome of no elections." 99 Justice Jackson's landmark opinion in Barnette has aged well and survived the test of time and history.

\section{Barnette's Doctrine: No Compelled Expression of Beliefs, Creeds, or Statements of Values}

Although some commentators believe that the doctrine of Barnette is "surprisingly difficult to defend" because some of its lyrical language "threatens to be overbroad," 100 the essential doctrine of the opinion is reasonably clear and has been liquidated and settled by subsequent Supreme Court decisions. 101 "Although it was once possible to read Barnette as only prohibiting government from compelling affirmations of belief, such as the Pledge of Allegiance, it soon became clear that the compelled speech doctrine also forbids government from compelling the

96 Barnette, 319 U.S. at 649 (Frankfurter, J., dissenting).

97 Id. at 647; see also id. at 667 ("And even though legislation relates to civil liberties, our duty of deference to those who have the responsibility for making the laws is no less relevant or less exacting. .. To strike down a law like this is to deny a power to all government.").

$98 \quad I d$. at 638 (majority opinion).

99 Id.

100 Blasi \& Shiffrin, supra note 45 , at 121.

101 See William Baude, Constitutional Liquidation, 71 STAN. L. REV. 1, 7 (2019) (citing NLRB v. Canning, 134 S. Ct. 2550, 2560 (2014)) (addressing the Supreme Court's acceptance of James Madison's view that the Constitution's meaning would likely need to be liquidated and settled over time). 
dissemination of unwanted expression." 102 Thus, under the Free Speech Clause, government may not compel a person to express or disseminate any belief, creed, or statement of values, whether it is the government's own message or the message of a third-party. ${ }^{103}$ Clearly, the government has power to express its own opinions, or to endorse the opinions of a third party, however, it may not compel a person to become an echo chamber for such opinions. ${ }^{104}$ Although the competing sides of various issues may use the political process to seek legislation adopting their opinions into law, "Barnette suggests one limit: one cannot insist that the victory of one side, of one creed or value, be memorialized by compelling the defeated side to literally give voice to its submission." 105

Moreover, the right to resist compelled expression does not require any conscientious objection to the compelled dogma. One cannot be compelled to express any idea, even one he or she might agree with. ${ }^{106}$ Nor is it necessary to demonstrate that one's objection is based upon fear of being publicly associated with a creed against one's will. ${ }^{107}$ None of these things matter. The purpose of the Barnette doctrine is to nip authoritarian and totalitarian government in the bud by protecting freedom of the mind, those "few cubic centimeters inside your skull," 108 from being controlled by laws or government policies compelling expression. Justice Jackson's opinion in Barnette is revered because it speaks to the hearts of those who love liberty. It deserves all of the honor that has been showered upon it.

102 Richard F. Duncan, A Piece of Cake or Religious Expression: Masterpiece Cakeshop and the First Amendment, NEB. L. REV. 6 (Jan. 7, 2019), https://awreview.unl.edu/piececake-or-religious-expression-masterpiece-cakeshop-and-first-amendment.

103 Id. at 6-8; see also Eugene Volokh, The Law of Compelled Speech, 97 TEx. L. REV. $355,368-70$ (2018) (discussing how the government may not compel people to say things they wish not to say).

104 Horwitz, supra note 53, at 724 ("[G]overnment is free...to offer various pronouncements that constitute an orthodoxy or 'officially preferred "right position."' What it cannot do is 'compel citizens to affirm such opinions."').

$105 \mathrm{Id}$. at 723 .

106 Id. at 724 .

107 Justice Frankfurter's dissent asserts that nothing in the compelled flag salute policy restricted the right of dissenting schoolchildren and their parents from publicly disavowing their support for any objectionable meaning contained in the flag salute. See W. Va. State Bd. of Educ. v. Barnette, 319 U.S. 624, 664 (1943) (Frankfurter, J., dissenting) ("All channels of affirmative free expression are open to both children and parents."). But, of course, that would effectively compel them to express both the ideas contained in the flag salute and their opposition to those ideas. It would compound the compelled speech burden and the violation of the sanctity of control over one's mind, one's thoughts, and one's beliefs by requiring multiple statements of belief and disbelief.

108 ORwELL, supra note 3, at 27. Or, to revisit Justice Jackson's words, the First Amendment protects "the sphere of intellect and spirit" from being invaded by governmental authorities. Barnette, 319 U.S. at 642. 


\section{Some of Barnette's Progeny: Herein of Creeds on License Plates and Compelled Expression in Parades}

In 1977, the Supreme Court decided Wooley v. Maynard to strike down a law that demonstrates that even states that proclaim their love of liberty can become authoritarian about their libertarianism. ${ }^{109}$ Although the "fighting faiths" of an era do not always age well,110 in their time they seem to be irrefutable and therefore universal. Such was the case in New Hampshire with its fighting truth, "Live Free or Die."111

The State of New Hampshire was so sure about the universal truth of its state motto that it required this homage to freedom to be embossed on all noncommercial license plates and, under another law, made it a misdemeanor to knowingly obscure "the figures or letters on any number plate." 112 George Maynard and his wife Maxine, the appellees in the case, were Jehovah's Witnesses who considered the motto "repugnant to their moral, religious, and political beliefs." 113 In order to avoid displaying this ideological message on their license plates, Mr. and Mrs. Maynard covered the motto with tape and soon found themselves in conflict with the law. ${ }^{114}$ Ironically, despite its motto to "Live Free or Die," New Hampshire repeatedly prosecuted $\mathrm{Mr}$. Maynard for obscuring the motto on his license plate. ${ }^{115}$ He actually served a brief sentence in jail for acting upon, rather than displaying, the "Live Free or Die" creed. ${ }^{116}$

The Supreme Court of the United States, in a majority opinion written by Chief Justice Burger, held that New Hampshire had violated the First Amendment by compelling "an individual to participate in the dissemination of an ideological message by displaying it on his private property." 117 It did not matter that Maynard was not required to actually speak any words, affirm any beliefs, or create or compose any expressive message. It was enough that the state had required him to act as a "mobile billboard for the state's ideological motto . . . [a]s a condition to driving an automobile-a virtual necessity for most Americans." 118 Moreover, the Court focused on an often-missed First Amendment problem in compelled speech cases-almost inevitably, these cases involve the state compelling

109430 U.S. $705,716-17$ (1977).

110 As Justice Holmes once observed, "time has upset many fighting faiths." Abrams v. United States, 250 U.S. 616, 630 (1919) (Holmes, J., dissenting)

111 Wooley, 430 U.S. at $706-07$.

112 Id. at 707 .

113 Id.

114 Id. at $707-08$

115 Duncan, supra note 102, at 6-7 (discussing how Maynard was prosecuted for covering up New Hampshire's libertarian credo).

116 Wooley, 430 U.S. at 707-08.

117 Id. at 713 .

118 Id. at 715 . 
not just speech, but a particular viewpoint, a free speech violation at the core of the First Amendment. ${ }^{119}$ As the Court explained: "The First Amendment protects the right of individuals to hold a point of view different from the majority and to refuse to foster, in the way New Hampshire commands, an idea they find morally objectionable." 120

Focusing on the First Amendment's protection of "individual freedom of [the] mind," 121 the Court stated the "no compelled speech" rule in clear and unqualified language:

We begin with the proposition that the right of freedom of thought protected by the First Amendment against state action includes both the right to speak freely and the right to refrain from speaking at all. A system which secures the right to proselytize religious, political, and ideological causes must also guarantee the concomitant right to decline to foster such concepts. ${ }^{122}$

The significance of Wooley is that it makes clear that the landmark doctrine of Barnette protects an individual's intellectual autonomy not merely from compelled affirmations of belief, but also from attempts by the state to compel an individual to speak or even to help disseminate any religious, political, or ideological creed.

The Supreme Court has also made clear that the First Amendment protects one private individual from being compelled by law to express, convey, or help disseminate the political, ideological, or social ideas of another private individual. Moreover, this doctrine applies even if the compelled third-party expression arises in the context of a public accommodations law that treats private expression as a public accommodation. ${ }^{123}$ In Hurley, the Court was tasked with deciding the reach of the no-compelled-speech doctrine in a case involving a sexual

119 Id. (discussing how Barnette dealt with a state measure that forced an individual to adopt a certain viewpoint)

$120 I d$. Although a content-based restriction of speech is a grievous First Amendment problem, viewpoint-based discrimination by government is a "more blatant" and "egregious form of content discrimination." Rosenberger v. Rector \& Visitors of Univ. of Va., 515 U.S. 819,829 (1995). Thus, when the government compels a private individual to express a particular ideological message or creed, as in Barnette and Wooley, it is an egregious viewpoint-based wrong under the First Amendment.

121 Wooley, 430 U.S. at 714 (citing W. Va. State Bd. of Educ. v. Barnette, 319 U.S. 624, 637 (1943)).

122 Id. (citations omitted)

123 Hurley v. Irish-Am. Gay, Lesbian \& Bisexual Grp. of Bos., Inc., 515 U.S. 557 , 573-74 (1995). See Duncan, supra note 102, at 7-8. 
orientation discrimination complaint against the organizers of the Boston St. Patrick's Day parade. ${ }^{124}$

The case arose when GLIB, a group "of gay, lesbian, and bisexual descendants of the Irish immigrants," wished to march in the Boston St. Patrick's Day Parade in order "to express pride in their Irish heritage as openly gay, lesbian, and bisexual individuals." 125 When the private sponsors of the parade, John J. "Wacko" Hurley and the South Boston Allied War Veterans Council, refused to allow GLIB to march as a group in the parade, GLIB sued to enforce the Massachusetts Public Accommodation law, which prohibits discrimination on the basis of sexual orientation "in any place of public accommodation, resort or amusement." 126 The state trial court held that the St. Patrick's Day Parade was a place of public accommodation under the law and that the Council's decision to ban GLIB because of "its values and its message" was illegal discrimination on the basis of sexual orientation. ${ }^{127}$

Moreover, in a wonderful exercise of authoritarianism, the trial judge stated that to deny GLIB the right to march in the parade was not only illegal, but also inconsistent with "a proper celebration" of St. Patrick's Day, which, according to the judge, "requires diversity and inclusiveness." 128 Perhaps there is no better example of Justice Jackson's iconic authoritarian official, the "village tyrant," than this presumptuous trial judge telling the private organizer of a holiday parade which values and ideas are required for a "proper celebration" of the holiday.

Before reaching the compelled speech issue in the case, the Supreme Court had to decide two preliminary matters. First, was the St. Patrick's Day Parade a type of expression protected by the First Amendment, or was it, as the state courts had concluded, "nonexpressive conduct" outside the protection of the Free Speech Clause?129 Second, was the Massachusetts public accommodation law a content-neutral prohibition of discrimination in the marketplace for goods and recreational services or, as applied to the private citizens promoting the parade, did it operate as a state-compelled expression of an ideological message? ${ }^{130}$ The Court answered both questions on the side of freedom of speech.

124 Hurley, 515 U.S. at 559.

125 Id. at 561.

$126 \mathrm{Id}$.

${ }_{127}$ Id. at 561-63. Remarkably, the trial judge said that rejection of the values and message of an LGBT group constitutes discrimination on the basis of the sexual orientation of the group's members. Id at 562. Apparently, discrimination against the message is, without more, discrimination against the person. Id.

$128 I d$. at 562 .

129 Id. at $567-68$.

130 Id. at 572 (noting that "on its face" the Massachusetts public accommodations law did not "target speech or discriminate on the basis of its content"). 
First, it held that the St. Patrick's Day Parade is a "form of expression" 131 even if it is not designed to express any particularized message about politics or ideology other than to march in celebration of St. Patrick and Irish-American heritage. ${ }^{132}$ As the unanimous majority opinion put it, the "protected expression that inheres in a parade is not limited to its banners and songs" or its intent to express any particular message. ${ }^{133}$ Like the abstract art of a painter such as Jackson Pollock, a parade celebrating a holiday is expression protected by the First Amendment even if it lacks "a narrow, succinctly articulable message." 134

As to the second issue, the Court stated that the Massachusetts public accommodations law, although facially targeting only discriminatory conduct-not speech - "has been applied in a peculiar way," 135 because the "state courts' application of the statute had the effect of declaring the [parade] sponsor's speech itself to be the public accommodation." 136 Thus, Justice Souter's unanimous opinion held that the state court order violated "the fundamental rule of protection under the First Amendment, that a speaker has the autonomy to choose the content of his own message." 137

The Court emphasized that the sponsors' objection to GLIB was not the sexual orientation of its members, who were not as individuals barred from marching in the parade, but rather "to the admission of GLIB as its own parade unit carrying its own banner." 138 In other words, the objection was to GLIB's message, not to its members as individual persons. As a result, the state courts had ordered the petitioners in effect "to alter the expressive content of their parade." 139

Justice Souter, writing for a unanimous Supreme Court, held that the state court's "mandate violates the First Amendment" 140 and compared the idea of speaker autonomy-the right of "a private speaker to shape its expression by speaking on one subject while remaining silent on another" - to that of a composer of music who selects which notes to include and which to exclude from his musical score. ${ }^{141}$ Thus, the constitutional ideal of intellectual autonomy for speakers, artists, and parade organizers, which originated in Barnette, now had the support of a unanimous Supreme Court.

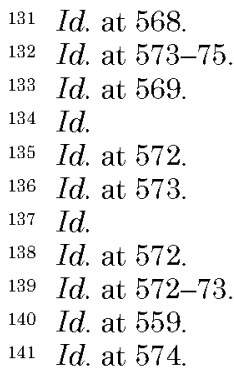


Hurley also illustrates some additional free speech concerns that typically arise from speech mandates. First, these mandates often involve viewpoint discrimination, because they compel the speaker to express either the government's viewpoint, as in Wooley, ${ }^{142}$ or the viewpoint of a third party, as in Hurley. For example, the mandate in Hurley, which required the sponsors of the parade to allow GLIB to march in support of gay pride, ${ }^{143}$ interfered with their right "not to propound a particular point of view." 144

Moreover, the law operated as an unconstitutional condition, because it required the sponsors of the parade to choose between two First Amendment rights, the right to speak and the right not to speak. ${ }^{145}$ Massachusetts required the sponsors to choose between their right to parade in support of their own expression, and their right to refrain from fostering the expression of GLIB. ${ }^{146}$ They could have "one constitutional right or the other, but not both;" "[t]he First Amendment does not permit government to put a speaker to that odious choice." 147

\section{JUSTICE KENNEDY GOES OUT LIKE A LION}

\section{A. Justice Kennedy's Last Hurrah: Authoritarianism and "Forward Thinking"}

Although some of Justice Kennedy's jurisprudence has been criticized as little more than bad poetry, or in the biting words of Justice Scalia, as echoing "the mystical aphorisms of the fortune cookie," 148 Kennedy has built a considerable jurisprudential legacy protecting freedom of speech under the First Amendment. ${ }^{149}$ Even in cases in which a majority voted to uphold a First Amendment claim, Kennedy's passionate concern for freedom of speech, particularly his strong objections to laws restricting speech on the basis of its content or viewpoint, often led him to write

142 See supra notes 109-122 and accompanying text.

143 Hurley, 515 U.S. at 561.

144 Id. at 575 (emphasis added).

145 See id. at 579 (stating that the law "is not free to interfere with speech for no better reason than promoting an approved message or discouraging a disfavored one").

$146 I d$.

147 See Duncan, supra note 102 , at 13 ; see also Volokh, supra note 103 , at 361 (government may not compel a speaker to include unwanted speech as a condition to expressing the speaker's own "speech product").

148 Obergefell v. Hodges, 135 S. Ct. 2584, 2630 n.22 (2015) (Scalia, J., dissenting).

149 See, e.g., Ashutosh Bhagwat \& Matthew Struhar, Justice Kennedy's Free Speech Jurisprudence: A Quantitative and Qualitative Analysis, 44 MCGEORGE L. REV. 167, 167 (2013) (describing Justice Kennedy's reputation as a free speech advocate); see generally KNOWLES, supra note 5, at 53-87 (discussing Justice Kennedy's free speech legacy); FRANK J. Colucci, Justice Kennedy's Jurisprudence: The Full and NeCessary MeAning of LIBERTY 75-101 (2009) (same). 
concurring opinions calling for "even greater protection" for freedom of expression. ${ }^{150}$

The Supreme Court's October Term 2017-2018 featured three compelled speech cases.151 Justice Kennedy was in the majority of all three. He wrote the majority opinion in one of them, ${ }^{152}$ joined the majority in a second, ${ }^{153}$ and joined the majority and wrote a powerful concurring opinion in the third. ${ }^{154}$

In Masterpiece Cakeshop, the compelled speech issue concerned a Christian wedding cake artist, Jack Phillips, who considered his custom cake creations to be "artistic expression celebrating the beauty of marriage as God designed marriage." 155 Therefore, although he was happy to serve all customers, without regard to sexual orientation, he could not in good conscience create wedding cakes designed to celebrate same-sex marriages. ${ }^{156}$ The state of Colorado enforced its public accommodations law against Mr. Phillips and ordered him to "cease and desist from discriminating against... same-sex couples by refusing to sell them wedding cakes or any product [he] would sell to heterosexual couples." 157 In other words, Colorado required Phillips to choose between his right as an artist to create custom wedding cakes celebrating opposite-sex marriage and his right not to create wedding cakes celebrating same-sex marriage. ${ }^{158}$

Because the no-compelled-speech doctrine was already well-established, the primary issue facing the Court under the Free Speech Clause was whether custom wedding cakes are artistic expression

150 See Int'l Soc. for Krishna Consciousness, Inc. v. Lee, 505 U.S. 672, 693 (1992) (Kennedy, J., concurring) (departing from the majority's reasoning, Justice Kennedy defined public forum more expansively, thereby shielding more areas from speech regulations); Simon \& Schuster, Inc. v. Members of N.Y. State Crime Victims Bd., 502 U.S. 105, 124 (1991) (Kennedy, J., concurring) (maintaining that content-discriminatory statutes should be per se unconstitutional); KNOWLES, supra note 5, at 67 (observing that during his years on the Supreme Court "Kennedy has staked out a lonely but brave position vociferously objecting to content-based regulations of speech" by writing separately even when the majority voted to uphold free speech rights).

151 October Term 2017, SCOTUSBLOG, https:/www.scotusblog.com/case-files/terms/ ot2017/ (last visited Feb. 22, 2020); Masterpiece Cakeshop, Ltd. v. Colo. Civil Rights Comm'n, 138 S. Ct. 1719 (2018); Janus v. Am. Fed'n of State, Cty. \& Mun. Emps., Council 31 (AFSCME), 138 S. Ct. 2448 (2018); Nat'l Inst. Of Family \& Life Advocates v. Becerra (NIFLA), 138 S. Ct. 2361 (2018).

152 Masterpiece Cakeshop, 138 S. Ct. at 1723.

153 Janus, $138 \mathrm{~S}$. Ct. at 2459.

154 NIFLA, $138 \mathrm{~S}$. Ct. at 2378 (Kennedy, J., concurring).

155 Duncan, supra note 102 , at 2 .

156 Id. at 3 .

157 Masterpiece Cakeshop, $138 \mathrm{~S}$. Ct. at 1726 (citation omitted).

158 See Duncan, supra note 102 , at 13 (noting the unconstitutional choice forced between the right to speak and the right to not speak). 
protected by the doctrine. ${ }^{159}$ In other words, are custom wedding cakes more like pizza or breadsticks served in an Italian restaurant, or like a sculpture or oil painting created by a fine artist. ${ }^{160}$ Masterpiece Cakeshop was particularly difficult for Justice Kennedy because it involved a "clash" between free speech and religious liberty on one side and gay rights and marriage equality on the other. ${ }^{161}$ Perhaps because of this clashing of interests, Justice Kennedy's majority opinion in Masterpiece Cakeshop did not decide the compelled speech issue. Instead, the Court held that Colorado had violated the Free Exercise Clause because the state did not treat Phillips with "the religious neutrality that the Constitution requires." 162

Although Justice Kennedy did not decide the compelled speech issue in Masterpiece Cakeshop, his opinion did contain some powerful dicta in support of Phillips' free speech claim. Speaking for the Court, Justice Kennedy observed that although the free speech issue in this case "is difficult, for few persons who have seen a beautiful wedding cake might have thought of its creation as an exercise of protected speech," 163 Phillips' claim "is an instructive example, however, of the proposition that the application of constitutional freedoms in new contexts can deepen our understanding of their meaning." 164 Moreover, "if a baker refuse[s] to design a special cake with words or images celebrating the marriage," these additional details "might make a difference." 165 These insights might well shed a great deal of light on future cases involving commercial artists and compelled artistic expression.

Justice Kennedy joined Justice Alito's majority opinion in a second important compelled speech case, Janus v. American Federation of State, County \& Municipal Employees, Council 31, ${ }^{166}$ in which the Court struck down a state law requiring public employees "to subsidize a union, even if they choose not to join and strongly object to the positions the union takes in collective bargaining and related activities." 167 This, said the Court,

159 Id. at $9,13$.

$160 \mathrm{Id}$

161 See Zachary S. Price, Symmetric Constitutionalism: An Essay on Masterpiece Cakeshop and the Post-Kennedy Supreme Court, 70 HASTINGS L.J. 1273, 1291 (2019) (noting the political conflict between traditional principles and civil rights equality). Some scholars believe the religious liberty holding in Masterpiece Cakeshop was a very narrow one. Id. I believe it is not necessarily a narrow holding. See Duncan, supra note 102, at 10-11, 23-24 (noting both the free speech and free exercise implications of the holding).

162 Masterpiece Cakeshop, $138 \mathrm{~S}$. Ct. at 1724

163 Id. at 1723.

$164 I d$.

165 Id.

166138 S. Ct. 2448, 2448, 2459 (2018).

167 Id. at 2459-60. 
violates the Free Speech Clause because it compels dissenting workers "to subsidize private speech on matters of substantial public concern." 168

The force of the no-compelled-speech doctrine as a defense against authoritarian government was strong in Janus. Justice Alito, speaking for Chief Justice Roberts and Justices Kennedy, Thomas, and Gorsuch observed that when government compels speech, it inflicts even more damage than when it merely restricts speech. ${ }^{169}$ This is so because it is "always demeaning" to compel "free and independent individuals to endorse ideas they find objectionable." 170 Invoking Thomas Jefferson, the Janus Court forcefully observed that to compel an individual to betray his personal convictions by subsidizing the ideas of another "is sinful and tyrannical." 171

Justice Kennedy's inspirational manifesto on the no-compelled-speech doctrine as a shield against authoritarian government, an opinion cementing his legacy as one of the greatest defenders of freedom of speech in Supreme Court history, was issued as a concurring opinion in NIFLA. ${ }^{172}$ In NIFLA, the state of California required pro-life crisis pregnancy centers to provide certain "government-drafted" notices ${ }^{173}$ to their clients and in their advertisements. For example, licensed pro-life clinics were required to "notify women that California provides free or low-cost services, including abortions" and to provide a phone number to learn more about those services. ${ }^{174}$ Justice Thomas, writing for a majority that included Justice Kennedy, held that this compelled expression was an unconstitutional "content-based regulation of speech." 175 But the real fireworks were provided by Justice Kennedy in a concurring opinion joined by Chief Justice Roberts and Justices Alito and Gorsuch.

Justice Kennedy made clear that he joined the majority opinion "in all respects," and was writing a separate opinion only to make an even stronger case against California's compelled speech law. ${ }^{176}$ Essentially, he wrote to underscore two points. First, that California was guilty of something more serious than a content-based regulation of speech; rather, the California law constituted "viewpoint discrimination" and served as "a paradigmatic example of the serious threat presented when government

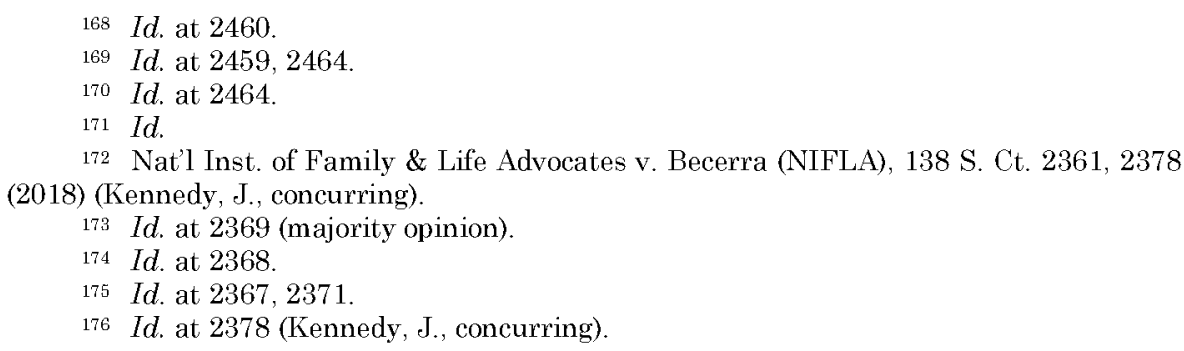


seeks to impose its own message in the place of individual speech." 177 Second, Justice Kennedy wrote an eloquent and powerful denunciation of compelled speech as a deplorable and tyrannical characteristic of authoritarian government.

Justice Kennedy described the compelled speech law as one in which California had required pro-life crisis pregnancy centers to disseminate the state's message "advertising abortions" and thereby "to contradict their most deeply held beliefs, beliefs grounded in basic philosophical, ethical, or religious precepts." 178 But what is even more noteworthy is Kennedy's response to the self-congratulatory statement by the California Legislature that "the Act was part of California's legacy of 'forward thinking." 179 Justice Kennedy observed that it is not "forward thinking" to compel ideological uniformity and continued:

It is forward thinking to begin by reading the First Amendment as ratified in 1791; to understand the history of authoritarian government as the Founders then knew it; to confirm that history since then shows how relentless authoritarian regimes are in their attempts to stifle free speech; and to carry those lessons onward as we seek to preserve and teach the necessity of freedom of speech for the generations to come. Governments must not be allowed to force persons to express a message contrary to their deepest convictions. Freedom of speech secures freedom of thought and belief. This law imperils those liberties. ${ }^{180}$

These words of Justice Kennedy, echoing the eloquent opinion of Justice Jackson in Barnette, ${ }^{181}$ are indeed inspirational words to share with our children when we endeavor to teach them about the blessings of liberty and the fundamental importance of both the right to speak and the

177 Id. at 2379 .

178 Id.

179 Id.

180 Id. Justice Kennedy also saw the specter of authoritarianism in his plurality opinion in the "stolen valor" case:

Permitting the government to decree this speech to be a criminal offense, whether shouted from the rooftops or made in a barely audible whisper, would endorse government authority to compile a list of subjects about which false statements are punishable. That governmental power has no clear limiting principle. Our constitutional tradition stands against the idea that we need Oceania's Ministry of Truth.

United States v. Alvarez, 567 U.S. 709,723 (2012). Justice Kennedy's reference to Oceania and its Ministry of Truth is, of course, to the description of Thought Police and thought crimes in George Orwell's greatest novel, 1984. Id.

181 See W. Va. State Bd. of Educ. V. Barnette, 319 U.S. 624, 641-42 (1943) (asserting that the government does not have the ability to coerce speech). 
right not to be compelled to speak. The no-compelled-speech doctrine is deeply-rooted in the Court's free speech jurisprudence and serves as a powerful defense against "authoritarian regimes" and their dark arts. ${ }^{182}$

\section{B. Compelled Speech in the Post-Kennedy Era: The Telescope Media Case}

On August 23, 2019, the United States Court of Appeals for the Eighth Circuit decided an important compelled speech case ${ }^{183}$ concerning a videography business, same-sex marriage, and the following question presented: "Carl and Angel Larsen wish to make wedding videos. Can Minnesota require them to produce videos of same-sex weddings, even if the message would conflict with their own beliefs?" 184 This case concerned Carl and Angel Larsen, a couple who own and operate Telescope Media Group, a business through which the Larsens produce and make films using "their "unique skill[s] to identify and tell compelling stories through video." 185 The Larsens insist that they "gladly work with all people-regardless of their race, sexual orientation, sex, religious beliefs, or any other classification," 186 however, because of their religious conscience and their desire to honor God, they are unwilling to produce or make films expressing messages that contradict biblical truths about abortion, racial equality, sexual morality, or marriage. ${ }^{187}$ Therefore, although they wish to make films promoting marriage as a "sacrificial covenant between one man and one woman," they cannot in good conscience produce videos that promote or celebrate same-sex marriage. ${ }^{188}$ Clearly, the Larsens' objection is to the message expressed by a video celebrating a same-sex marriage, not to the identity of the customers who wish to commission the video.

Under Minnesota's public accommodations law, however, the Larsens were required "to produce both opposite-sex and same-sex-wedding videos, or none at all." 189 Moreover, at oral argument in the case, the state of Minnesota made clear that the Larsens must be willing to "depict same- and opposite-sex weddings in an equally 'positive' light" or be guilty of unlawful discrimination on the basis of sexual orientation. ${ }^{190}$ Minnesota thus viewed its public accommodation laws as requiring wedding videographers to express a positive viewpoint about

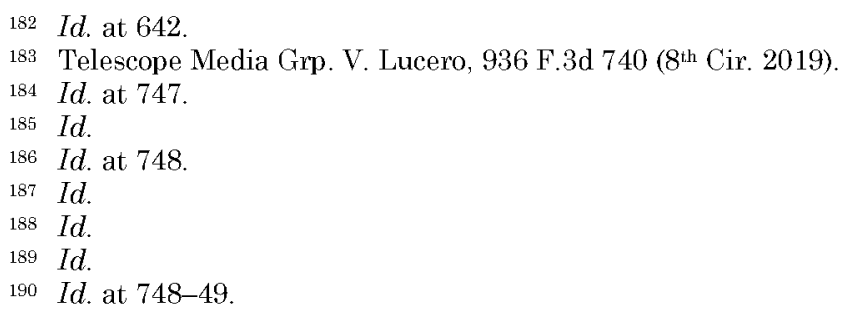


same-sex marriage without regard to the filmmakers' deeply-held religious and ideological views about the definition and the good of marriage. ${ }^{191}$ Moreover, in addition to civil remedies, violation of Minnesota's antidiscrimination law is a crime punishable by fines and jail. 192

The district court granted Defendants' motion to dismiss; ${ }^{193}$ however the Eighth Circuit reversed by a two to one vote. ${ }^{194}$ The primary free speech issue before the court was whether Minnesota's public accommodation laws, as applied to a wedding videographer who objected to making videos expressing a positive view of same-sex marriage, constituted merely the regulation of conduct and not speech. ${ }^{195}$ Does the law primarily regulate the conduct of the Larsens' commercial wedding service, or does it compel the Larsens to "speak favorably about same-sex marriage if they choose to speak favorably about opposite-sex marriage." 196

The majority in Telescope Media, in a powerful and persuasive opinion by Judge Stras, concluded that, "Speech is not conduct just because the government says it is." 197 The court made clear that wedding videography is "a form of speech that is entitled to First Amendment protection" 198 and that it makes no "difference that the Larsens are expressing their views" about the meaning and sanctity of marriage "through a for-profit enterprise." 199 The court found that Minnesota's threatened enforcement of the public accommodation laws against the Larsens "is at odds with the 'cardinal constitutional command' against compelled speech." 200 Moreover, since the law "compels the Larsens to speak favorably about same-sex marriage if they choose to speak favorably about opposite-sex marriage[,]...[i]t operates as a content-based regulation of their speech." 201

Actually, since it compels positive speech about same-sex marriage, it arguably constitutes a viewpoint-based speech mandate-if the Larsens make videos expressing their actual views about the sanctity of traditional

191 Id. at 748.

192 See Telescope Media Grp. V. Lindsey, 271 F. Supp. 3d 1090, 1098 \& n.4 (D. Minn. 2017) (noting that violation of the statute is a misdemeanor, which is punishable by jail time of up to ninety days and/or a fine of up to $\$ 1,000)$, aff'd in part, rev'd in part and remanded sub nom., 936 F.3d 740 ( $8^{\text {th }}$ Cir. 2019).

193 Telescope Media Grp.Lindsey, 271 F. Supp. 3d at 1097.Id. at 63.

194 Telescope Media Grp., 936 F.3d at 762

195 Id. at 752.

196 Id.

$197 \mathrm{Id}$. at 747,752

198 Id. at 750 .

199 Id. at 751.

200 Id. at 752 (quoting Janus v. Am. Fed'n of State, County \& Mun. Emps., Council 31, 138 S. Ct. 2448, $2463(2018))$.

201 Id. at 752 . 
marriage, they are compelled by law to contradict their own beliefs and express an equally-positive viewpoint about same-sex marriage. In other words, the law requires the Larsens to speak about marriage with a forked tongue. Thus, as in Hurley, ${ }^{202}$ although on their face Minnesota's public accommodation laws are content-neutral regulations of conduct, as applied to the Larsens' wedding videos these laws are content- or even viewpoint-based speech mandates that violate the no-compelled-speech doctrine of Barnette, Wooley, Hurley, NIFLA, and many other cases. As Justice Kennedy made so clear in his NIFLA concurrence, it is not "forward thinking" to compel ideological uniformity about the equal goodness of opposite-sex and same-sex marriage. ${ }^{203}$ The First Amendment is a powerful defense against authoritarian government and its relentless attempts to "force persons to express a message contrary to their deepest convictions." 204

CONCLUDING THOUGHTS:

WHY THE No-COMPELLED-SPEECH DOCTRINE MATTERS

"There was truth and there was untruth, and if you clung to the truth even against the whole world, you were not mad." -George Orwell ${ }^{205}$

Starting in Barnette and most recently in Janus and NIFLA, the Supreme Court has strongly declared that government may not "coerce uniformity of sentiment" 206 on issues of public concern by compelling expression of beliefs, creeds, or statements of values. This doctrine is of fundamental importance in any society that believes, in the words of Justice Kennedy quoted near the beginning of this article, that "The right to think is the beginning of freedom, and speech must be protected from the government because speech is the beginning of thought."207 Therefore, free men and free women must have autonomy over their speech, over that which they choose to say and that which they choose not to say.

202 Hurley v. Irish-Am. Gay, Lesbian and Bisexual Grp. of Bos., Inc., 515 U.S. 557, 561 (1995); see also supra notes 121-138 and accompanying text.

203 Nat'l Inst. of Family \& Life Advocates v. Becerra (NIFLA), 138 S. Ct. 2361, 2378

(2018) (Kennedy, J., concurring); see also supra notes 178-182 and accompanying text.

204 NIFLA, 138 S. Ct. at 2379 (Kennedy, J., concurring).

205 ORWELL, supra note 3, at 217.

206 W. Va. State Bd. of Educ. v. Barnette, 319 U.S. 624, 640 (1943); see also Janus v Am. Fed'n of State, Cty. \& Mun. Emps., Council 31, 138 S. Ct. 2448, 2460 (2018) (concluding that non-members cannot be compelled to support the speech of union members); NIFLA, $138 \mathrm{~S}$. Ct. at 2371 (holding that forcing pro-life cris is pregnancy centers to advertise for statesubsidized abortions was improper).

207 Ashcroft v. Free Speech Coal, 535 U.S. 234, 253 (2002). 
Alexander Solzhenitsyn, a dissident imprisoned for his activism by the totalitarian regime of the former Soviet Union, ${ }^{208}$ has captured the essence of the right not to speak as being based upon each individual's conscience and commitment to the truth as he or she understands it. ${ }^{209}$ In an essay entitled Live Not By Lies, Solzhenitsyn said "let us refuse to say that which we do not think," 210 and went on to explain that "an honest man[,] worthy of [the] respect both by [his] children and [his] contemporaries ... [w]ill not depict, foster or broadcast a single idea which he can only see is false or a distortion of the truth whether it be in painting, sculpture, photography, technical science, or music."211 As Orwell explained in 1984, his seminal novel of life in fictional Oceania under a totalitarian regime that used extreme coercion to mandate uniformity of opinion, if an individual "clung to the truth" as he understood it, he might against all odds maintain his human dignity and his sanity. ${ }^{212}$ Solzhenitsyn put it even more clearly: "And the simplest and most accessible key to our self-neglected liberation lies right here: Personal non-participation in lies. Though lies conceal everything, though lies embrace everything, but not with any help from me." 213

Although our society in no way resembles the tyrannical totalitarianism of 1984's Oceana, we nevertheless frequently encounter "village tyrants" who use the law to compel citizens to speak, publish or create expression adopting the favored message of the state or a third person, or to attend "rallies or lectures espousing the right views." 214 According to Kelly Sarabyn, such coercive methods are deployed "in order

208 Charles E. ZiEGLER, THE History OF RUSSIA 102 (2d ed. 2009) (revealing that Solzhenitsyn was imprisoned for eight years and exiled for three years simply for making derogatory comments about Stalin in his personal correspondence to his family); The Editors of Encyclopaedia Britannica, Aleksandr lsayevich Solzhenitsyn, ENCYCLOPAEDIA BRITANNICA, https://www.britannica.com/biography/Aleksandr-Solzhenitsyn (last visited Mar. 17, 2020) (explaining how Solzhenitsyn endured prison, labor camps, and exile for his politically critical works).

209 See Alexander Solzhenitsyn, Live Not By Lies, ORTHOdOXY TODAY http://www. orthodoxytoday.org/articles/SolhenitsynLies.htm (last visited Mar. 2, 2020) (noting that to liberate themselves, people should refuse to believe the lies the government tells them).

210 Id

211 Id.

Solzhenitsyn penned this essay in 1974 and it circulated among Moscow's intellectuals at the time. It is dated Feb. 12, the same day that secret police broke into his apartment and arrested him. The next day he was exiled to West Germany. The essay is a call to moral courage and serves as light to all who value truth.

Id. (emphasis omitted).

212 ORWELL, supra note 3, at 217; see generally Duncan, supra note 102, at 5 .

213 Solzhenitsyn, supra note 209

214 See Kelly Sarabyn, Prescribing Orthodoxy, 8 CARdozo Pub. L., POL. \& ETHICS J. 367,373 (2010) (noting methods by which government can compel psychological agreement). 
to change citizens' ideological beliefs." 215 These are the petty tyrants and the authoritarian tactics that Justice Jackson and Justice Kennedy warned of in Barnette and NIFLA. And the no-compelled-speech doctrine is a powerful defense against our village tyrants and their dark arts.

The no-compelled-speech doctrine is thus best understood as a fundamental human right - a legal, political, and moral entitlement - that protects "sovereignty of the mind" 216 and individual autonomy over "the few cubic centimeters inside your skull" 217 from attempts by government to promote orthodoxy by compelling speech on matters of public concern. ${ }^{218}$ Moreover, the doctrine recognizes that speech compelled by government is almost always content-based, or even worse, viewpoint-based. ${ }^{219}$ This is even the case when a general, facially-neutral law prohibiting some form of conduct is applied to regulate speakers or artists. In other words, when government applies a law to compel a speaker to speak or create a particular message, as in Hurley, the restriction compels the content or viewpoint expressed by that particular message. ${ }^{220}$

Perhaps the best dramatic example of authoritarian government and compelled speech is found in Robert Bolt's wonderful play about Sir Thomas More, A Man For All Seasons. ${ }^{221}$ In the play, King Henry has commanded Thomas More to sign a statement effectively blessing the King's divorce and remarriage. ${ }^{222}$ As a faithful Catholic, More cannot sign. ${ }^{223}$ His conscience requires silence. ${ }^{224}$ In this remarkable excerpt from the play, two of the King's officials, Thomas Cromwell and Richard Rich, discuss the King's motives for refusing to allow More to keep his silence:

$215 I d$

216 Horwitz, supra note 53, at 727. Professor Horwitz describes Justice Jackson's opinion in Barnette as recognizing "a kind of paean to the sovereignty of the mind-in a legal sense, a political sense, and perhaps a larger sense altogether." Id.

217 ORWELL, supra note 3 , at 27.

218 Horwitz, supra note 53 , at 727

219 A content-based law would be one that compels an individual to say whatever he wishes about a particular subject, for example, on the subject of abortion. A viewpoint-based law would be one that compels an individual to express a particular viewpoint on a subject, for example to express a view in favor of abortion as in NIFLA. See supra notes 177-178 and accompanying text. It should be obvious that most instances of compelled speech are viewpoint-based.

220 See supra notes 142-144 and accompanying text.

221 Robert Bolt, A MAN For All SEasons: A Play in Two ACts (1st ed., Vintage Int'l 1990) (1962)

222 Id. at vii-x, xii-xiii.

223 Id. at xiii.

224 Id. at xii, 132-33 (explaining that More could not agree to sign because he would be going against his conscience; and even if he did sign, his agreement would not make the king's action right). 
Cromwell The King's a man of conscience and he wants either Sir Thomas More to bless his marriage or Sir Thomas More destroyed.

Rich They seem odd alternatives, Secretary.

Cromwell Do they? That's because you're not a man of conscience. If the King destroys a man, that's proof to the King that it must have been a bad man, the kind of man a man of conscience ought to destroy-and of course a bad man's blessing's not worth having. So either will do. ${ }^{225}$

Cromwell's point, of course, captures the essence of authoritarian government and the importance of the no-compelled-speech doctrine as understood by Justice Jackson and Justice Kennedy. If the King succeeds in compelling More's blessing for his divorce and remarriage, he has won the blessing of a good man, a man whose blessing justifies the King's conduct. ${ }^{226}$ But if More refuses to bless the marriage, he will be treated as an outlaw, as a bad man whose opinions are worthless. ${ }^{227}$ The King wins either way. And liberty loses either way.

Compelled speech about political and religious beliefs-whether concerning patriotism and the flag, ${ }^{228}$ the relative value of life versus liberty, ${ }^{229}$ gay pride and St. Patrick's day, ${ }^{230}$ the definition of marriage, ${ }^{231}$ or the morality of abortion ${ }^{232}$ - is always a threat to freedom of thought and the dignity of individuals who wish to remain silent about certain subjects or viewpoints.

Looking back on Barnette, Wooley, Masterpiece, and NIFLA, it is difficult not to admire the courage of the dissenters who risked their education, their livelihood, and their liberty to defend freedom of thought, speech, and religious conscience against the tyranny of speech mandates. Many, but not all, of the compelled speech cases concerned Jehovah's Witnesses or other religious minorities resisting attempts by authoritarian officials to impose some notion of official orthodoxy of

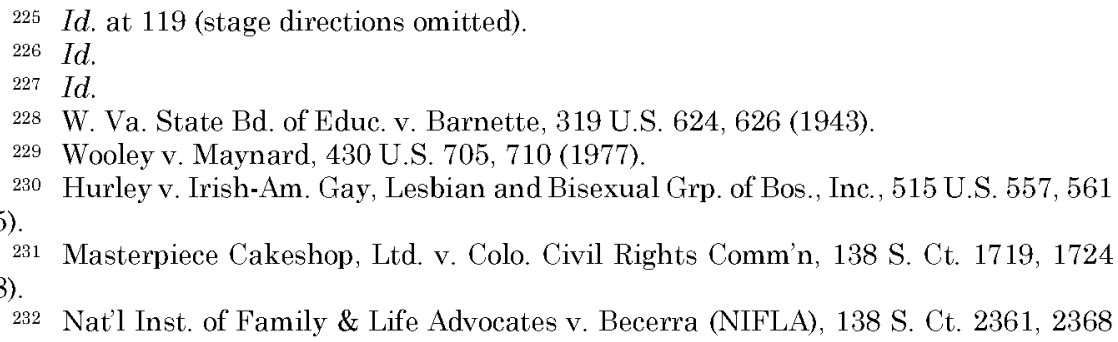


thought and speech on dissenting citizens. ${ }^{233}$ Sarah Berringer Gordon wrote eloquently concerning Justice Jackson's warning about orthodoxy leading to the "unanimity of the graveyard" and focused specifically on the role of religious dissenters in this line of cases: "Religious dissenters, when seen from this perspective, are like the canary in the coal mine: When they begin to suffer and die, everyone should be worried that the atmosphere has been polluted by tyranny." 234

The no-compelled-speech doctrine is designed to nip tyranny and authoritarianism in the bud when petty and not-so-petty tyrants use law to compel free men and women "to say that which [they] do not think." ${ }^{235}$ From Justice Jackson in Barnette to Justice Kennedy in NIFLA, the Court has employed the Free Speech Clause as a powerful shield protecting freedom of thought and speaker autonomy against authoritarian laws compelling speech. Under the no-compelled-speech doctrine, no schoolchild, no automobile owner, no parade organizer, no artist, and no individual may be compelled to say that which they do not think.

We owe a great debt to Justice Jackson, Justice Kennedy, and many other jurists who have faithfully nurtured this fundamental First Amendment protection against village tyrants and authoritarian speech mandates. But the decision in NIFLA was five to four. ${ }^{236}$ To paraphrase Benjamin Franklin, the no-compelled-speech doctrine is a fundamental First Amendment right only "if we can keep it." 237

233 E.g., Barnette, 319 U.S. at 629 (Jehovah's Witnesses); Wooley, 430 U.S. at 707 (Jehovah's Witnesses); Masterpiece Cakeshop, 138 S. Ct. at 1724 (Christian cake artist); NIFLA, $138 \mathrm{~S}$. Ct. at 2368 (mostly Christian crisis pregnancy centers).

234 Sarah Berringer Gordon, What We Owe Jehovah's Witnesses, AM. Hist., April 2011, at 41 .

235 See supra notes $206-211$ and accompanying text

236 NIFLA, 138 S. Ct. at 2367.

237 When Benjamin Franklin was asked by a passerby on the streets of Philadelphia what kind of government had been established by the Constitutional Convention, he responded: "A republic, if you can keep it." NEIL M. GORSUCH, A REPUBLIC, IF YOU CAN KEEP IT 8 (2019). 